\title{
H3-3A wt Allele
}

National Cancer Institute

\section{Source}

National Cancer Institute. H3-3A wt Allele. NCI Thesaurus. Code C101444.

Human H3-3A wild-type allele is located in the vicinity of $1 \mathrm{q} 42.12$ and is approximately 10

$\mathrm{kb}$ in length. This allele, which encodes histone H3.3 protein, plays a role in both

nucleosome assembly and transcriptional regulation. 